\title{
Heat-stress-modulated induction of NF-KB leads to brucellacidal pro-inflammatory defense against Brucella abortus infection in murine macrophages and in a mouse model
}

Huynh Tan Hop ${ }^{1 \dagger}$, Lauren Togonon Arayan ${ }^{1 \dagger}$, Alisha Wehdnesday Bernardo Reyes ${ }^{1}$, Tran Xuan Ngoc Huy ${ }^{1}$, Won Gi Min ${ }^{1}$, Hu Jang Lee', Man Hee Rhee ${ }^{1}$, Hong Hee Chang $^{3}$ and Suk Kim ${ }^{1,3^{*}}$ (D)

\begin{abstract}
Background: Brucella causes a chronic and debilitating infection that leads to great economic losses and a public health burden. In this study, we demonstrated the brucellacidal effect of heat shock mediated by the induction of pro-inflammatory cytokines, reactive oxygen species (ROS) accumulation and apoptosis in murine macrophages and in mice.

Results: RAW264.7 cells were incubated at $43^{\circ} \mathrm{C}$, and BALB/C mice were subjected to whole body hyperthermia. The data showed a reduction in bacterial survival in the mice after daily heat exposure. This was accompanied by increased levels of cytokines TNF, IL-6, IL-1 $\beta$ and IFN- $\gamma$ in the sera of the mice. Gene expression of NF-kB and inducible nitric oxide production were also induced in the mouse splenic cells. In parallel with the bacterial reduction in the mouse model, an increased bactericidal effect was observed in RAW264.7 cells after exposure to heat stress. In addition, the heat stress increased both the nuclear translocation of NF-KB and the expression of the heat shock proteins HSP70 and HSP90 in murine macrophages. Furthermore, heat exposure induced the increase of pro-inflammatory cytokines, ROS accumulation and apoptosis but did not affect the production of nitric oxide (NO) in macrophages.

Conclusion: This study demonstrated the induction of innate immune responses by heat stress that significantly reduced the intracellular survival of $B$. abortus in vitro and in vivo. Transcriptional factor NF-kB, which is a master regulator, could be termed a key activator of heat-induced immunity against Brucella. The increase in the expression and activation of NF-KB in splenic cells and macrophages was followed by enhanced antimicrobial effectors, including cytokines, ROS and NO that may contribute to the reduction of bacterial survival.
\end{abstract}

Keywords: B. abortus, Heat stress, Macrophage, NF-KB, ROS

\footnotetext{
* Correspondence: kimsuk@gnu.ac.kr

Huynh Tan Hop and Lauren Togonon Arayan contributed equally to this

work.

${ }^{\dagger}$ Equal contributors

'Institute of Animal Medicine, College of Veterinary Medicine, Gyeongsang

National University, Jinju 52828, Republic of Korea

${ }^{3}$ Institute of Agriculture and Life Science, Gyeongsang National University,

Jinju 52828, Republic of Korea

Full list of author information is available at the end of the article
}

(c) The Author(s). 2018 Open Access This article is distributed under the terms of the Creative Commons Attribution 4.0 International License (http://creativecommons.org/licenses/by/4.0/), which permits unrestricted use, distribution, and reproduction in any medium, provided you give appropriate credit to the original author(s) and the source, provide a link to the Creative Commons license, and indicate if changes were made. The Creative Commons Public Domain Dedication waiver (http://creativecommons.org/publicdomain/zero/1.0/) applies to the data made available in this article, unless otherwise stated. 


\section{Background}

The ability to resist and modify cellular activities for survival during stress is a fundamental property of eukaryotes and prokaryotes. Particular stressors, including heat shock, can elicit a stress response that affects an organism's immunity against a particular pathogen. Previous studies demonstrated a protective role of heat shock against sepsis and acute lung injury $[1,2]$. Heat shock can modulate the signal transduction associated with the pro-inflammatory responses. The heat shock response has been associated with the induction of heat shock proteins, and it is one of the proposed mechanisms by which pro-inflammatory responses are modulated in favor of the host defense. However, the effect of heat stress in the context of Brucella infection is not yet elucidated. Some studies suggest that heat stress can activate pathogen recognition receptors in antigen-presenting cells, including macrophages, which are important for the recognition of pathogen-associated molecular patterns [3]. Heat shock induced upregulation of these receptors might lead to a heightened response to invading pathogens [3]. The activation of many Toll-like receptor complexes specific for bacterial lipopolysaccharides and expressed on macrophages triggers the induction of inflammatory genes as well as cytokines [4]. Toll-like receptor signaling pathways all lead to the activation of the nuclear factor-kappaB $(\mathrm{NF}-\mathrm{kB})$, which plays a critical role in orchestrating the expression of inflammatory genes $[5,6]$. Interestingly, one study demonstrated the activation of NF- $\mathrm{kB}$ in rat liver after subjecting rats to heat stress [7], and another study showed the upregulation of the NF- $\mathrm{KB}$ pathway in monocytes under heat stress [3].

Macrophages play a major role in innate immunity. These cells recognize and respond to elevation in temperature and danger signals coming from inflammatory sites via pattern recognition receptors that eventually lead to the expression of heat shock proteins, antimicrobial products, as well as cytokine production [8].

From this premise, we try to evaluate the effects of heat stress through simulation via the heat-stress protocol that may mediate inflammation and subsequently influence brucellacidal activity.

In the present study, a stress response in murine macrophages and in mice subjected to B. abortus 544 infection was evaluated. In previous studies, macrophages exposed to heat stress displayed a greater capacity for phagocytosis and bacterial killing via rapid phagosome maturation against infection by group B Streptococcus [9]. Elevated temperature was the first stimulus discovered to induce heat shock proteins and other factors. Thermal stress triggers an intricate biochemical adaptive mechanism and gene expression that is favorable to the survival of the host. Hyperthermia can cause changes in gene expression.
Typically, the exposure of mammalian cells in vitro to temperatures between $42{ }^{\circ} \mathrm{C}$ and $45{ }^{\circ} \mathrm{C}$ can induce heat shock; however, the results may be variable according to the type of tissue used [10]. Heat shock can be induced in the mouse by a heat shock protocol (whole body hyperthermia) followed by reversion to normal temperature at $37{ }^{\circ} \mathrm{C}$ [11].

Brucella infection remains one of the most significant zoonoses in the world. It causes a chronic and debilitating infection that leads to great economic losses and public health burdens [12]. The Centers for Disease Control and Prevention (CDC; USA) includes Brucella spp. in the select agent list because of its significant infection rate. Infection can be acquired via the respiratory and gastrointestinal routes from infected tissues as well as by ingestion of unpasteurized products [13].

Brucella spp. have the ability to circumvent the killing mechanisms of the host [14]. The chronicity of infection is due to the strategies evolved by these species. One significant feature is the ability to inhibit the induction of host pro-inflammatory responses. In one study, the lack of leukocyte recruitment as well as cellular and humoral responses was demonstrated in a mouse model. To cause this effect, the pathogen can invade the host cell prior to the development of defensive host mechanisms. Thus, a minimal degree of pro-inflammatory responses leads to the protection of intracellular Brucella [15]. Another mechanism used by Brucella is the inhibition of apoptosis of infected macrophages to maintain a protective environment that sustains a niche for its intracellular growth [15]. In this study, we evaluated the expression of cleaved caspase-3, which is considered to be a key effector caspase, being activated by caspase- 8 and caspase-9. The activity of the caspases regulates the biochemical events that lead to the disassembly and eventual death of cells. The initiation of apoptosis is either via the mitochondrial or the death-receptor pathway mediated through caspase- 9 and caspase-8, respectively, which in turn activate the main effector, caspase-3 [16].

The effect of heat stress on the expression of antimicrobial effectors was also evaluated. The regulation of mammalian immune responses has been reported to be influenced by the expression of nitric oxide (NO). As shown in previous studies, NO plays a role in Brucella infection [17]. Macrophage-mediated cytotoxicity is involved as an antimicrobial mechanism. Macrophages are also capable of eliciting regulatory molecules, including reactive oxygen species, which can regulate the intracellular growth of B. abortus [18].

\section{Results}

Exposing mice to heat shock restricts bacterial infection Mice were sacrificed 14 days post-infection. The spleens and livers were collected and weighed. Daily 
exposure of mice to heat stress for $1.5 \mathrm{~h}$ after the initial infection on day 1 resulted in a reduced bacterial burden in the spleen and liver compared to control mice (Fig. 1a). The spleen weight of the treated mice was significantly different from that of the control mice; however, there was no significant difference in the liver weight (Fig. 1b, c).

\section{Heat stress induced cytokine production in splenic cells and sera of mice}

Cytokine expression in mouse splenic cells and their concentrations in sera were evaluated through RT-PCR and FACS or sandwich ELISA, respectively. An increased expression of Tnf, Il6, Illb, Ifng and Il10 was apparent in splenic cells of infected mice exposed to heat; however, Mcp1 was decreased (Fig. 2a). In parallel, the production of TNF (Fig. 2b), IL-6 (Fig. 2c), IL-1 $\beta$ (Fig. 2d), and IFN- $\gamma$ (Fig. 2f) was also elevated, and the level of monocyte chemoattractant protein-1 (MCP-1) was decreased in the infected group (Fig. 2e).

\section{Heat stress caused the increase of NF-KB and iNOS gene expression in splenic cells}

$\mathrm{NF}-\kappa \mathrm{B}$ is a central transcription factor responsible for controlling the expression of multiple cytokine genes involved in inflammatory responses, including TNF, IL-1, IL-6, IL-8 and IL-12, as well as NO production. To clarify the role of NF- $\mathrm{BB}$ in the heat shock response, the expression of the NF- $\mathrm{kB}$ subunit was investigated. Intriguingly, we found that members of the NF- $\mathrm{KB}$ family of transcription factors, p50 and p65, in infected splenic cells were upregulated under heat shock. In contrast, p52 was unchanged compared with the control (Fig. 3a). Western blot analysis showed that all three transcription factors were significantly increased in splenic cells infected and exposed to heat stress (Fig. 3b). This was accompanied by an upregulation of inducible nitric oxide synthase (iNOS) (Fig. 3c).
Bacterial killing activity evaluated in murine macrophages exposed to heat stress

To evaluate the effect of heat stress-induced responses on bacterial pathogenesis, macrophages were pretreated prior to infection. As shown in Fig. 4a, bacterial internalization of $B$. abortus was not affected by pretreatment with heat. However, a significant reduction in the intracellular growth of $B$. abortus was observed after infection followed by heat exposure. This reduction was maintained up to $24 \mathrm{~h}$ post-infection (Fig. 4b). Consistent with these data, bone marrow-derived macrophages (BMM) subjected to hyperthermia were also shown to enhance the resistance to $B$. abortus infection up to $48 \mathrm{~h}$ post-infection compared to the control (Fig. 4c).

\section{Heat stress accelerated heat shock protein expression} and NF-KB nuclear translocation but not NO production Heat shock proteins (HSPs) which are induced in response to heat stress were found to be a stimulator of antigen presentation process and immune response activation in immune cells. Particularly, HSP 90 and 70 were shown to interact with Toll-like receptor (TLR) 2 and 4 that induce the activation of NF- $k$ B pathway leading to subsequent production of pro-inflammatory cytokines (TNF and IL-12) and antimicrobial effector NO [19] . Interestingly, in this study, we found that heat exposure induced a marked expression of HSPs (Fig. $5 \mathrm{a}$ ) and NF- $k$ B activation (Fig. 5b, c) in infected macrophages which was consistent with observation in splenic cells; however it did not influence the production of NO (Fig. 5d) in B. abortu$s$-infected RAW 264.7 cells.

\section{Heat stress induces pro-inflammatory cytokine} expression, ROS production and apoptosis in B. abortusinfected macrophages

Infected macrophages with or without heat stress were subjected to cytokine mRNA measurements, ROS quantification and evaluation of Casp-3 activation. Pro-inflammatory cytokines, including TNF, IL-6 and IL-1 $\beta$ but not IL-10, were significantly elevated under heat stress in both of RAW 267.4 (Fig. 6a) and BMM

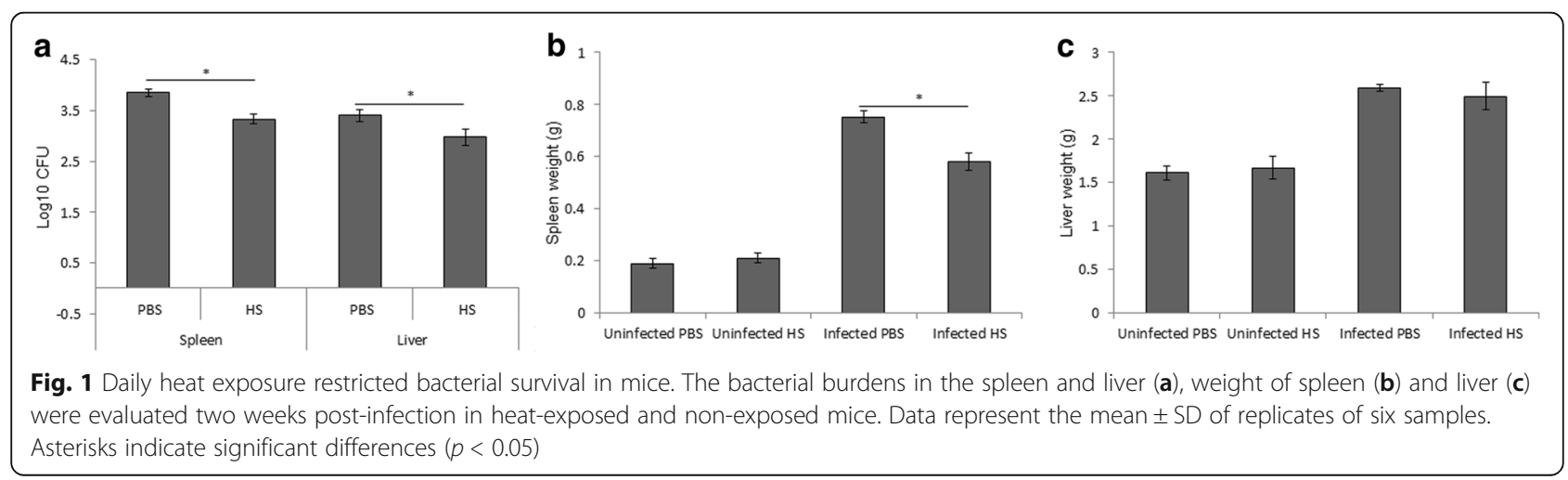




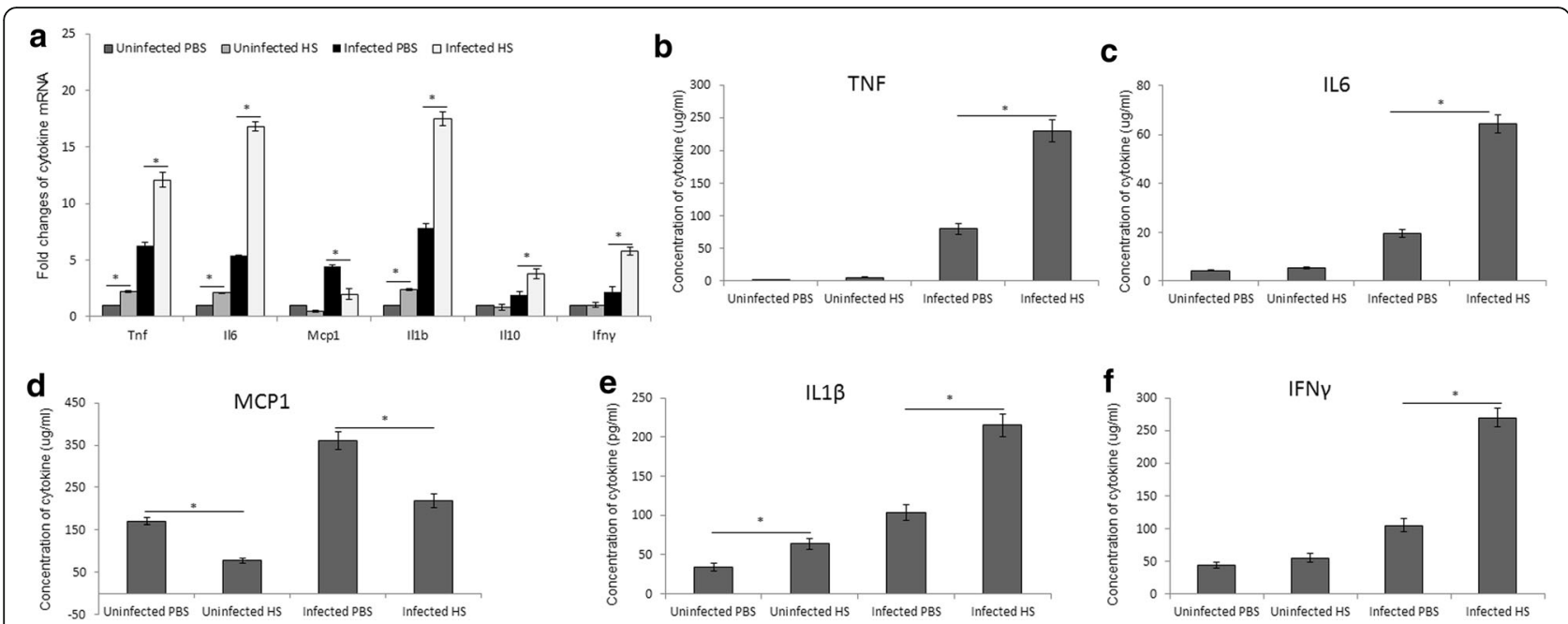

Fig. 2 Heat stress induced cytokine secretion. Expression of cytokines $\| 6$, II1b, Tnf, Mcpl, Ifng and $\| 10$ by mouse splenic cells with and without exposure to heat quantified by RT-PCR (a). Quantification of cytokines: TNF (b), IL-6 (c), IL-1 $(\mathbf{d}), M C P-1(\mathbf{e})$, and IFN- $\gamma(\mathbf{f})$ in the sera of mice by flow cytometer and sandwich ELISA. Data represent the mean \pm SD of replicates of six samples. Asterisks indicate significant differences $(p<0.05)$

(Fig. 6b) cells. In addition, the RAW 267.4 cells also exhibited increased production of ROS (Fig. 6c, d) and upregulation of cleaved caspase-3 (Fig. 6f). To further identify the source of heat stress-induced intracellular ROS accumulation in infected RAW 264.7 cells, we treated cells with either thenoyltrifluoroacetone (TTFA) or diphenylene iodinium (DI) which are inhibitors of mitochondrial respiratory chain and NADPH oxidase (NOX), respectively. Interestingly, the treatment with TTFA, but not DI significantly inhibits the heat stress-induced intracellular ROS accumulation in infected cells (Fig. 6e). To complement the activation of caspase-3, we further evaluated apoptosis by flow cytometry assay. As expected, the heat exposure induced the apoptosis in B. abortus-infected RAW 264.7 cells (Fig. 6g, h).

\section{Discussion}

This study demonstrated an enhancement of brucellacidal effect in vivo and in vitro mediated by the upregulation of the transcription factor, NF- $\mathrm{kB}$ and the subsequent induction of pro-inflammatory cytokines. Invading pathogens are attacked by the innate immunity as the first line of defense. Recognition of infectious agents by macrophages through toll-like receptors can initiate the signaling of the $\mathrm{NF}-\kappa \mathrm{B}$ cascade. One stealthy mechanism of Brucella is its ability to cause very minimal inflammatory responses compared with other bacterial infections at the onset of infection enabling it to persist chronically. Recognition of a pathogen-associated molecular pattern is the major requirement for the induction of inflammatory responses. One study demonstrated the upregulation of TLR2 and TLR4 in monocytes induced by heat stress [3]. These
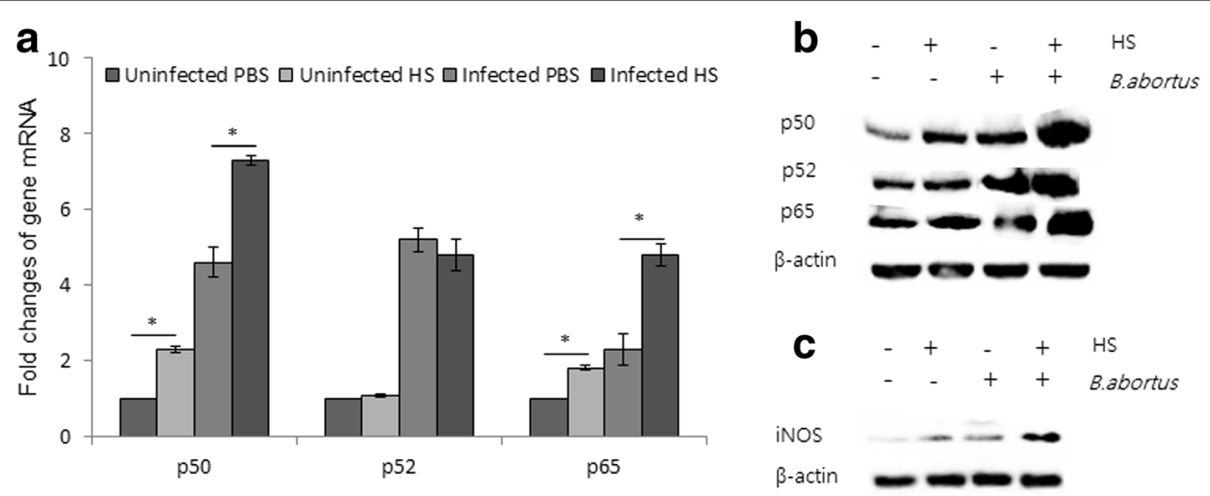

Fig. 3 Heat stress caused an increase in NF- $\mathrm{KB}$ and iNOS expression in splenic cells. The expression of heterodimers of NF- KB: p50, p52 and p65 from splenic cells was quantified by RT-PCR (a). Immunoblot analysis of the expression of heterodimers of NFkB: p50, p52 and p65 from splenic cells (b). Immunoblot analysis of iNOS expression following heat exposure (c). Asterisks indicate significant differences $(p<0.05)$ 

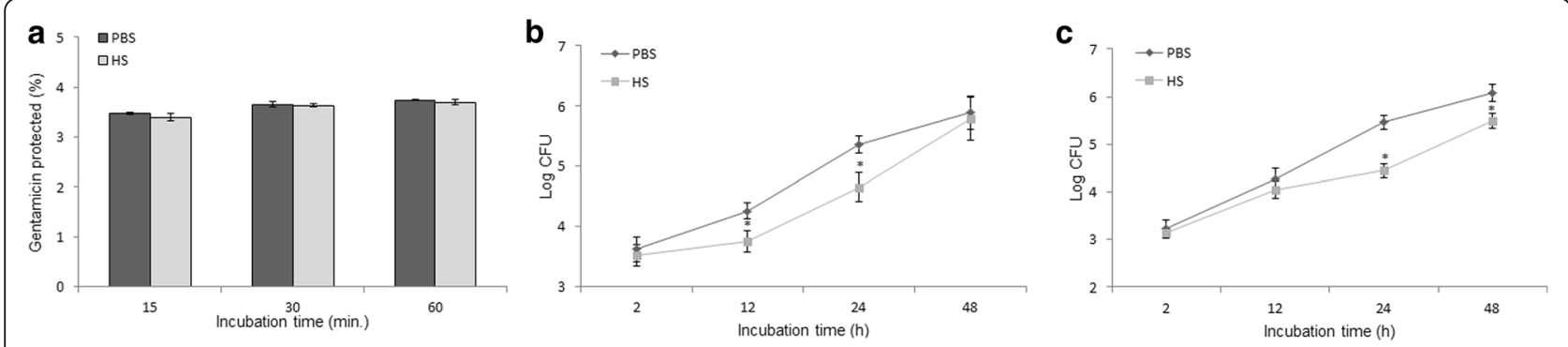

Fig. 4 Bacterial killing activity was evaluated in murine macrophages exposed to heat stress. Bacterial internalization of B. abortus after treatment with heat stress (a). Intracellular growth of B. abortus in RAW 264.7 cells initially infected and exposed to heat (b). Intracellular growth of $B$. abortus in BMM initially infected and exposed to heat (c). Data represent the mean \pm SD of triplicate experiments. Asterisks indicate significant differences $(p<0.01)$

receptors have been observed to be highly expressed peaking within $9 \mathrm{~h}$ and $6 \mathrm{~h}$, respectively, after heat exposure. Previous studies suggested that activation of these receptors might be an independent mechanism because it precedes the induction of heat shock proteins [3]. The induction of the heat shock response prior to any subsequent stress, including infections, has been demonstrated to be beneficial; however, the exact mechanism has not been elucidated [20]. Likewise, we suggest that the upregulation of NF- $\mathrm{kB}$ and the induction of proinflammatory cytokines manifested in this study are possibly influenced by the effect of heat stress on these toll like receptors as demonstrated in various studies showing upregulation of TLR2 and TLR4 [3]. The participation of TLRs; TLR2 and TLR4 in the recognition of Brucella infection has been documented in several studies. TLR2 was proposed to be able to induce IL-6, IL-12, TNF- $\alpha$, and IL-10 upon stimulating peritoneal macrophages with $B$. abortus lipoproteins, such as Omp16 and Omp19 [21]. Interestingly, the involvement of TLR4 with non-canonical Brucella LPS activates the induction of NF- $\mathrm{KB}$, stimulate the maturation of dendritic cells in response to its interaction with the protein; lumazine synthase [22] as well as upregulate the expression of co-stimulatory molecules and major histocompatibility class II (MHCII) in addition to the expression of TNF- $\alpha$, IL-12p70 and IL-6 [23].

Previous studies have shown enhanced phagocytosis and the bacterial killing of group B Streptococcus in macrophages that were subjected to heat shock [9]; however, in the present study, pretreating macrophages with

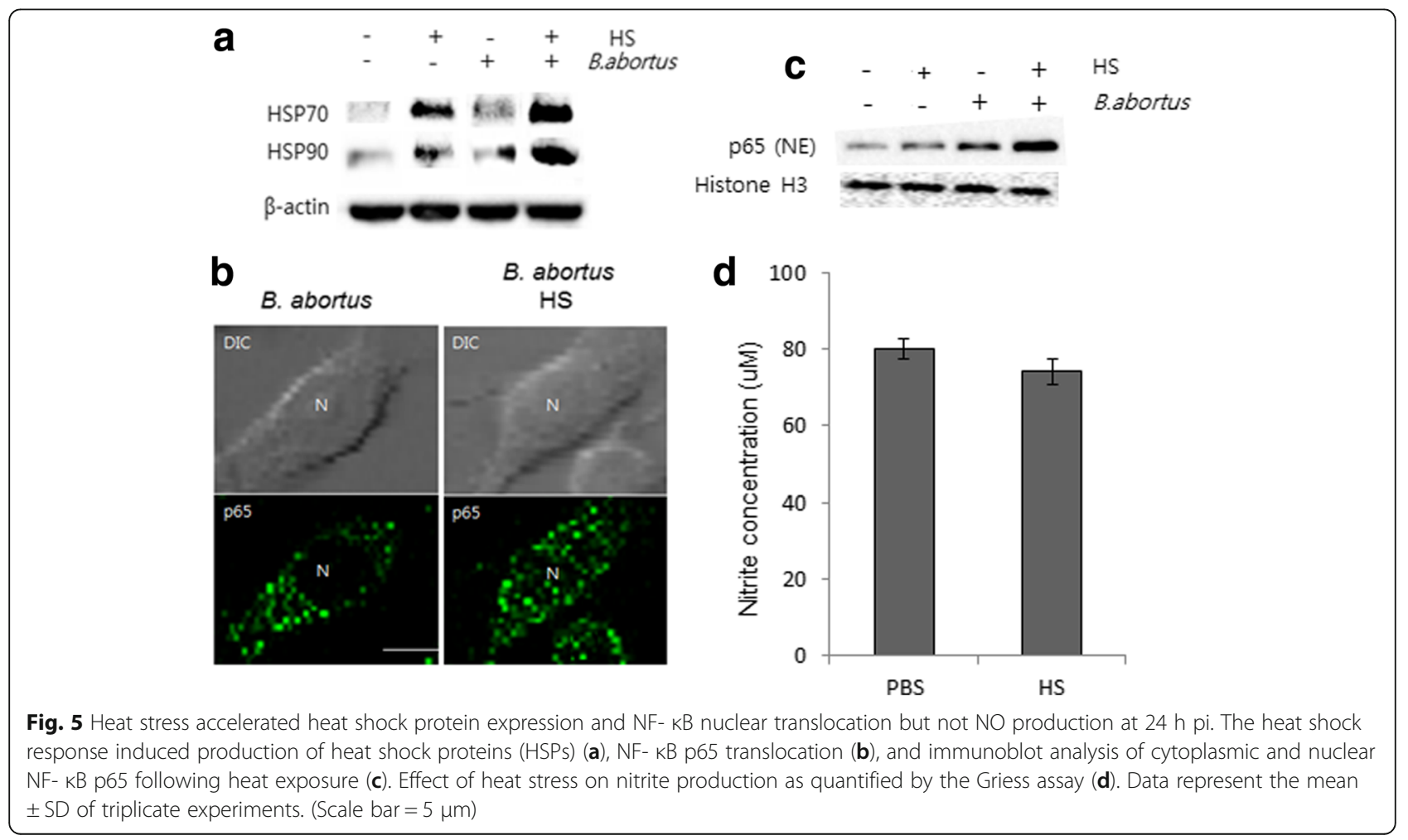



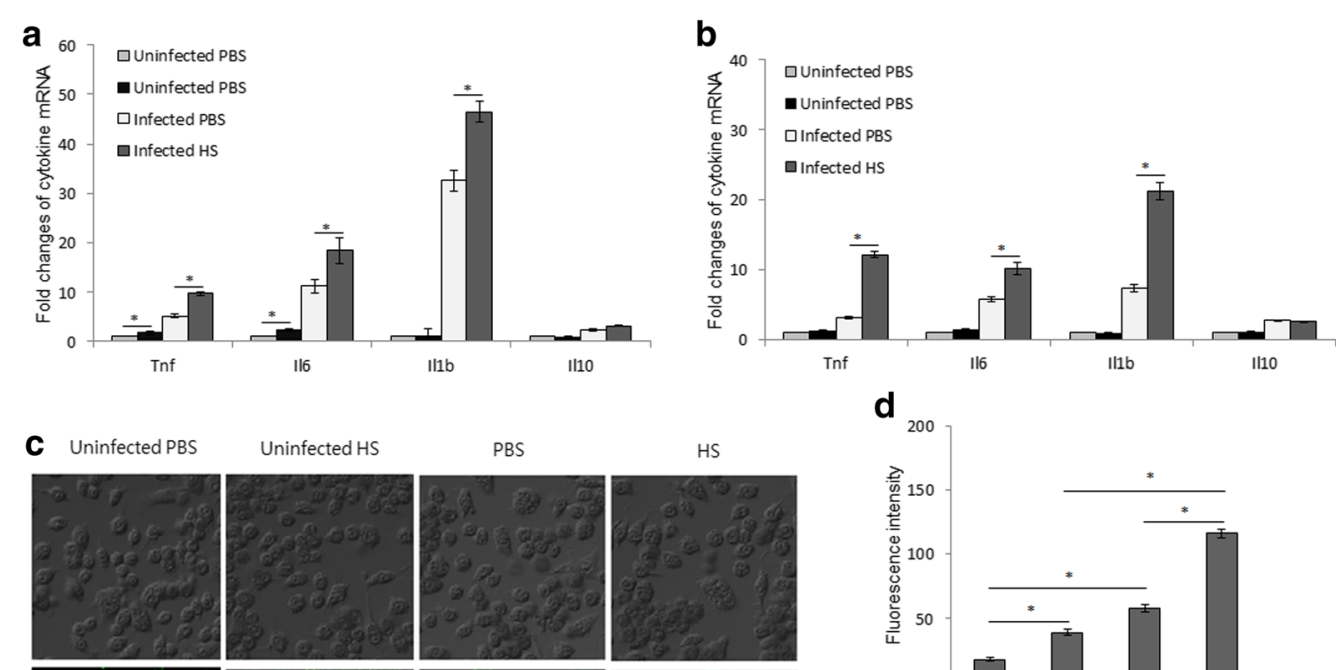

Uninfected HS PBS
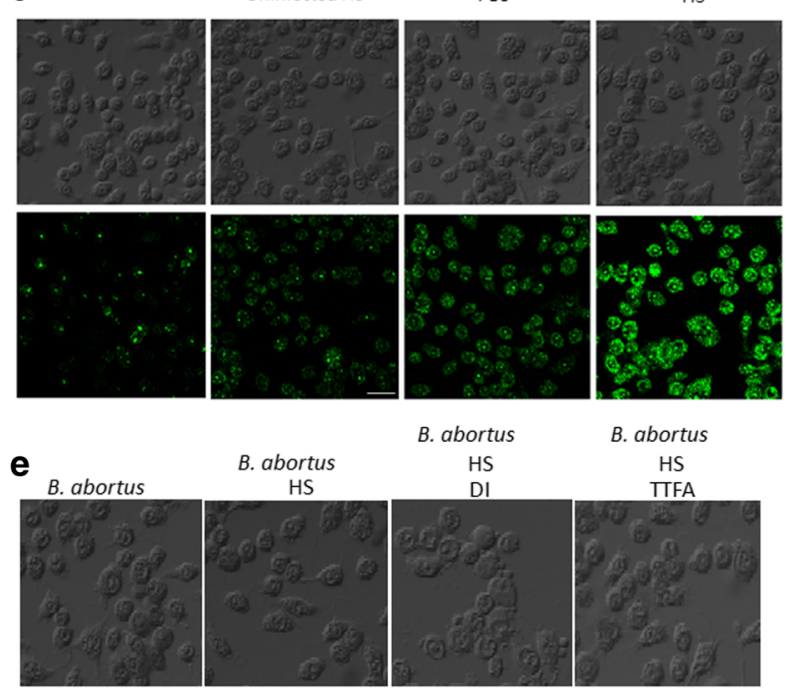

B. abortus
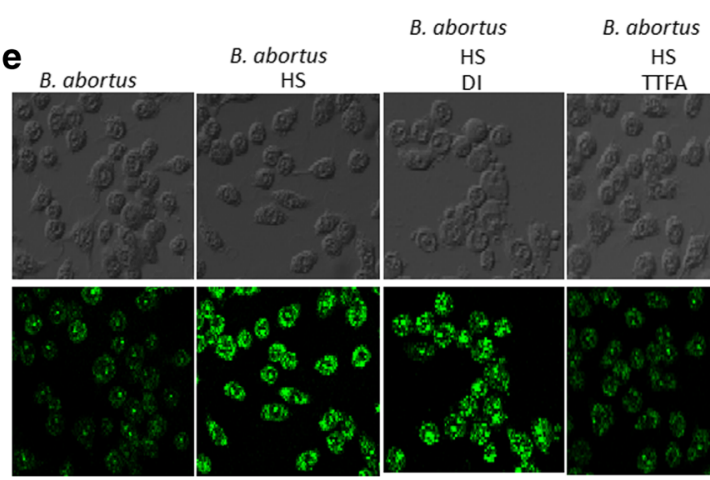

HS

HS

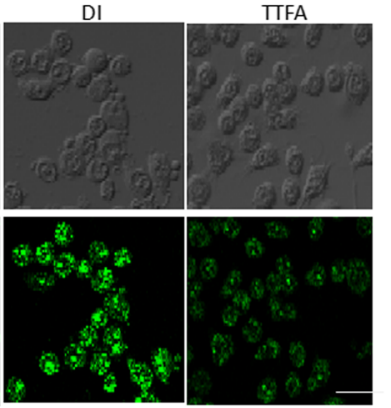

h

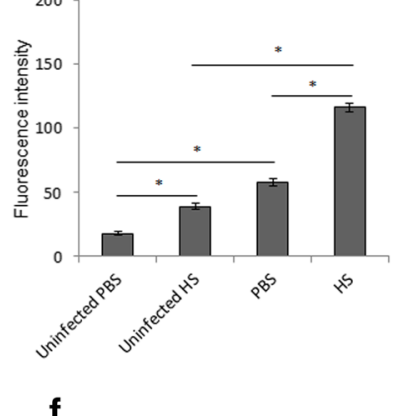

f

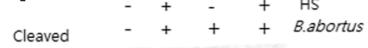

Cleaved

Caspase $3 \longrightarrow$

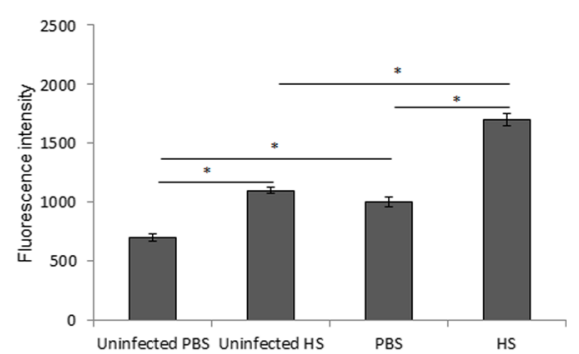

g
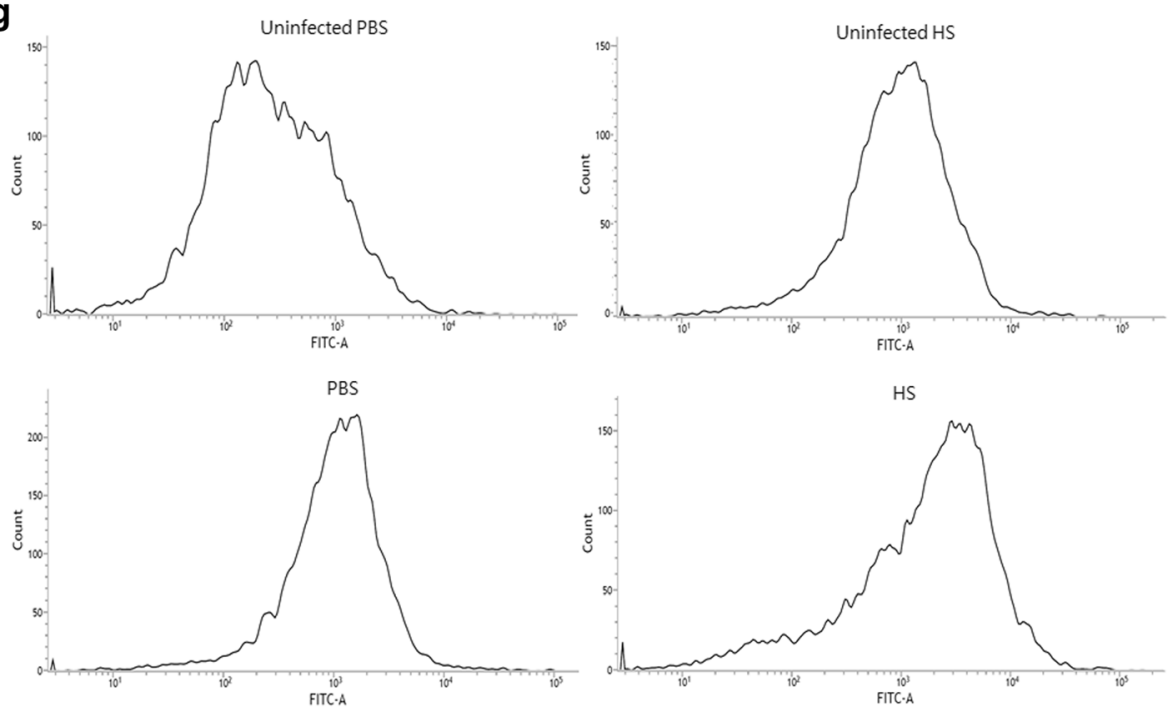

Fig. 6 (See legend on next page.) 
(See figure on previous page.)

Fig. 6 The effect of heat stress on the production of pro-inflammatory cytokines, ROS accumulation and apoptosis. The cells were infected with B. abortus and subjected to heat exposure. The production of pro-inflammatory cytokines and ROS was evaluated at $24 \mathrm{~h}$ pi while the apoptosis assay was performed at $48 \mathrm{~h}$ pi. Levels of pro-inflammatory cytokines: Tnf, I/6, II10, $/ 11 \mathrm{~b}$ and Mcp1 in RAW 264.7 (a) and BMM (b) through RT-PCR. Production of ROS after heat exposure was measured by fluorescence microscopy (c) and spectrometry (d). The infected cells were treated with inhibitors of mitochondrial respiratory chain (TTFA) or NADPH oxidase (DI) (e). The apoptosis was evaluated by activation of caspase-3 (f) and flow cytometry $(\mathbf{g})$ after heat exposure. The intensity of FITC was also evaluated from random 10,000 cells (h). Data represent the mean \pm SD of triplicate experiments. Asterisks indicate significant differences $(p<0.01)$. (Scale bar $=20 \mu \mathrm{m})$

heat prior to Brucella infection did not cause any effect on the rate of bacterial internalization compared with the control. In contrast, intracellular growth was restricted up to $24 \mathrm{~h}$ after infection, suggesting that the heat shock response in murine macrophages might affect the signaling of receptors during the course of infection even when subjected to heat exposure post-infection with Brucella. In parallel to the in vitro result, the mouse model demonstrated reduced survival of Brucella after two weeks of daily exposure to heat.

Inflammation can activate NF- $\mathrm{BB}$ as demonstrated in several diseases. The expression of NF- $\mathrm{kB}$ plays an important role in the defense against invading pathogens. The NF- $\mathrm{kB}$ family is composed of five critical regulatory transcription factors in mammalian cells: RelA (p65), RelB, p105 (the precursor of p50), p100 (the precursor of p52) and c-Rel. These proteins form either homo or heterodimers among themselves that can regulate the expression of distinguishable but co-occurring genes responsible for stress responses, including genes encoding heat shock proteins and genes involved in inflammation, innate and adaptive immunity, anti-apoptosis, proliferation and cancer progression [24, 25]. The heterodimer RelA-p50 is the most active form associated with TLR signaling [5] and interestingly, was the most highly expressed among the p52 and p65 dimers in the infected splenic cells subjected to heat. Under normal conditions, in the absence of stimulation, sequestration of NF- $\mathrm{kB}$ in the cytoplasm is controlled by inhibitor proteins called $\mathrm{I} \kappa \beta$ proteins. The inactive form of NF- $\mathrm{kB}$ can be made active by translocation to the nucleus [5]. This important event might be responsible for the induction of pro-inflammatory cytokines, including IL6 that can be induced by $\mathrm{p} 50$ and p65 in the rheumatoid arthritis pathology, as previously reported. In human monocytes, heterodimers of p65 and p50 activate the pro-inflammatory genes TNF- $\alpha$ and IL-1 $\beta$ [6] as well as other molecules and enzymes, including acute phase proteins and iNOS, which can have a favorable effect on cell survival in the presence of bacterial pathogens.

Interestingly, in this study, we found that the nuclear translocation and expression of nuclear p65 in murine macrophages is prominent after heat treatment and is followed by a marked increase in the production of important cytokines, including TNF, IL- 6 and IL-1 $\beta$ but not IL-10. This is consistent with a study reporting that heat stressed macrophages demonstrated an increased response to lipopolysaccharide (LPS) treatment followed by NF-kB translocation [26].

In Gram-negative infections, accelerated recognition of LPS by mammalian cells, particularly macrophages, leads to a heightened response against LPS and lipoproteins and subsequent release of pro-inflammatory mediators, including IL-6, IL-12, IL-1 $\beta$ and TNF- $\alpha$. This response benefits the host by enhancing inflammation at moderate levels, priming an enhanced immunity for the clearance of invading pathogens [27].

Our results showed significant elevation of the pro-inflammatory cytokines TNF, IFN- $\gamma$, IL- 6 and, more importantly, IL-1 $\beta$ in the sera and splenic cells of mice exposed to heat stress. In addition, the effect of heat stress on the expression of another killing effector, NO, was determined. The results showed upregulation of the iNOS gene in splenic cells of heat-stressed Brucella-infected mice but not NO production in murine macrophages. NO can regulate the immune response in mammalian cells, and it acts on intracellular pathogens and an array of other infectious agents, including viruses and fungi. The role of $\mathrm{NO}$ as a significant molecule in Brucella infection is well established [16]. NO is produced by the enzyme NO synthase, and its antimicrobial effect depends on macrophage-mediated cytotoxicity. In particular, macrophages release regulatory molecules, including reactive oxygen intermediates, which have a role to play in the control of the growth of B. abortus [18]. The expression of the inducible form of iNOS is responsible for the massive induction of $\mathrm{NO}$, and it is induced by pro-inflammatory cytokines, including TNF- $\alpha$, IL-1 and IFN- $\gamma$ [28]. It has also been shown that endogenous TNF- $\alpha$ is required for the production of reactive oxygen intermediates that confer anti-Brucella activities to macrophages [29]. The significant elevation of ROS in macrophages might contribute to the clearance of Brucella observed in this study.

Among several cytokines, IFN- $\gamma$ and TNF- $\alpha$ are key to Brucella infection. The IFN- $\gamma$-mediated Th1 immune response is thought to be essential to the control of Brucella infection, and in its absence, there 
is diminished bacterial clearance [30]. In contrast, production of IL-10, a counter-regulator of IFN- $\gamma$ during the early onset of infection, is beneficial for the pathogen, promoting intracellular replication by setting a level conducive for the survival of the pathogen [18]. In this study, however, heat stress did not induce significant differences in IL-10 in splenic cells and sera from infected mice and from the controls. IL-1 $\beta$ induces the release of other pro-inflammatory cytokines, including TNF and IL-6, and activates the Th17 bias of the cellular adaptive responses [31]. In turn, IL-6 is highly elevated, consistent with previous articles, which reported that IL- 6 could be detected in the sera of mice after endotoxin challenge [26]. In contrast, MCP-1 is attenuated by heat stress in both sera and splenic cells, but it is required for monocyte recruitment from bone marrow to the site of inflammation [32].

As previously reported, increases in the cytokines TNF- $\alpha$ and IL- 6 and the concurrent production of NO and iNOS have been correlated with the induction of HSP70 in heat-treated macrophages subjected to IFN- $\gamma$ and LPS stimulation [33]. However, more investigations are required to elucidate the effect of heat stress on Brucella pathogenesis.

Another important virulence factor of $B$. abortus that contributes to the chronicity of this infection is its ability to inhibit macrophage apoptosis in infected cells. Sustaining macrophage viability provides an intracellular niche that is important in circumventing the antagonistic external environment and allowing an environment conducive to bacterial replication [34]. Brucella infection will cause the expression of A1 of the blc2 family, which is an anti-apoptotic gene [35]. Other bacteria, including Yersinia spp., utilizing the deubiquitinating protease YopJ were documented to be able to retain IKB sequestered in the cytoplasm, inhibiting nuclear translocation and the subsequent prevention of the induction of protective pro-inflammatory cytokines [36]. The upregulation of the subunits of NF-kB and the subsequent nuclear translocation under heat stress might contribute to counter the anti-apoptotic ability of $B$. abortus in addition to the enhancement of pro-inflammatory cytokines that are brucellacidal in nature.

In conclusion, the brucellacidal effect of heat stress demonstrated in this study might be attributed to several factors. One possible mechanism is the influence of heat stress in the upregulation of Toll-like receptors during infection, which may sustain and heighten responsiveness to $B$. abortus that leads to an enhanced response along the signal transduction cascade culminating in the activation of NF-KB, as demonstrated in this study. These events led to the induction of pro-inflammatory cytokines that restrict bacterial survival in macrophages and in the mice. NF- $\mathrm{kB}$, in turn, is highly associated with the regulation of the transcription of heat shock proteins, which in itself can modulate the expression of transcription factors [10]. However, this is another aspect that requires further investigation.

This study illustrated the antimicrobial effects of heat stress in macrophages and mouse model in response to $B$. abortus infection through the activation of NF- $\mathrm{kB}$ pathway leading to the induction of pro-inflammatory cytokines, antimicrobial effectors (ROS and NO) and apoptosis. These effects results in an enhanced reduction in the intracellular survival of $B$. abortus in vitro and in vivo.

\section{Methods}

Bacteria and cell culture

B. abortus 544 (ATCC 23448), a smooth, virulent $B$. abortus biovar 1 strain was used in this study. It was cultivated in Brucella broth (Becton Dickinson, MD, USA) or on Brucella agar and grown at $37{ }^{\circ} \mathrm{C}$ with vigorous shaking until it reached the stationary phase. RAW 264.7, a murine cell line, was grown at $37{ }^{\circ} \mathrm{C}$ in $5 \% \mathrm{CO}_{2}$ atmosphere in RPMI medium (Thermo Fisher Scientific, MA, USA) containing 10\% heat-inactivated fetal bovine serum, with or without $100 \mathrm{U} / \mathrm{ml}$ penicillin and $100 \mu \mathrm{g} /$ $\mathrm{ml}$ streptomycin (all purchased from Gibco, Invitrogen, CA, USA).

\section{BMM preparation}

Bone marrow-derived macrophages (BMM) from female $\mathrm{BALB} / \mathrm{c}$ mice were prepared and incubated at $37^{\circ} \mathrm{C}$ with $5 \% \mathrm{CO}_{2}$ atmosphere as previously described [37]. BMMs were cultured in cultivation dishes $(100 \mathrm{~mm} \times 20 \mathrm{~mm})$ with $10 \mathrm{ml} \mathrm{L}$-cell conditioned medium. After 5 days of incubation, $10 \mathrm{ml}$ fresh medium without antibiotics was added and the cells were incubated further for 5 days. After 10 days of incubation, BMMs were washed three times with PBS and incubated with fresh RPMI 1640 medium containing $10 \%(\mathrm{v} / \mathrm{v})$ heat-inactivated fetal bovine serum (FBS).

\section{Bacterial uptake and intracellular growth}

To monitor bacterial uptake, internalization assay was performed as previously described [38]. Briefly, macrophages at $10^{6}$ cells per well were maintained in RPMI containing $10 \%(\mathrm{v} / \mathrm{v})$ fetal bovine serum (RPMI/10\% FBS) and subjected to $43{ }^{\circ} \mathrm{C}$ for $1.5 \mathrm{~h}$ following infection with bacteria at a multiplicity of infection (MOI) of 100, centrifuged at $150 \mathrm{xg}$ for $10 \mathrm{~min}$ at room temperature and incubated at $37{ }^{\circ} \mathrm{C}$ in $5 \% \mathrm{CO}_{2}$. At 0,30 and $60 \mathrm{~min}$ post-infection, the infected cells were washed once with phosphate buffer saline (PBS) and then incubated in RPMI $/ 10 \%$ FBS and gentamicin $(30 \mu \mathrm{g} / \mathrm{ml})$ for $30 \mathrm{~min}$ to kill extracellular bacteria. Finally, the cells were washed 
with PBS, lysed with distilled water and plated on Brucella agar.

To monitor intracellular growth, the macrophage maintained in RPMI/10\% FBS were infected with $B$. abortus at MOI of 100 and incubated for $2 \mathrm{~h}$ at $37{ }^{\circ} \mathrm{C}$. The cells were then transferred to $43{ }^{\circ} \mathrm{C}$ for $1.5 \mathrm{~h}$ and returned to $37{ }^{\circ} \mathrm{C}$ for further incubation. At 2, 24 or $48 \mathrm{~h}$ post-infection, RPMI/10\% FBS containing gentamicin $(30 \mu \mathrm{g} / \mathrm{ml})$ was added and incubated for $30 \mathrm{~min}$. The cells were then washed with PBS, lysed with distilled water and plated on Brucella agar.

\section{Infection of mice with $B$. abortus 544}

Female BALB/c mice, 8 weeks old (Japan SLC, Japan) were randomly allocated into four groups with six mice per group (uninfected with and without heat shock, infected with and without heat shock) and housed in standard conditions with ad libitum access to food pellets and water. Acclimatization of one week preceded the intraperitoneal infection with $B$. abortus 544 at a concentration of $5 \times 10^{5}$ colony forming unit (CFU)/ mouse used. The exposure to heat shock is as previously reported [11] with few modifications. At $24 \mathrm{~h}$ post-infection, the mice were subjected daily to hyperthermia at $43{ }^{\circ} \mathrm{C}$ for $1.5 \mathrm{~h}$ and returned back to room temperature and daily for 13 days. They were sacrificed on the 14th day post-infection, and sera, spleens and livers were collected. The spleens and livers were weighed and spliced approximately $0.5 \mathrm{mg}$ each sample for homogenizing in PBS. The homogenates were diluted 100-fold with PBS and plated on Brucella agar and then incubated for 3 days at $37{ }^{\circ} \mathrm{C}$. The $\log _{10}$ number of CFUs for each spleen sample was calculated.

\section{Total RNA extraction}

DNase-treated RNA was isolated from spleens as previously described, following the manufacturer's protocol [39]. Briefly, macrophages and splenic cells were subjected to RNA extraction using RiboEx reagent (Geneall,
South Korea) and RNeasy ${ }^{\circ}$ Mini kits (Qiagen, Germany). RNase-free DNase 1 (Qiagen, Korea) was used to remove genomic DNA contamination. The purified RNA was collected and stored at $-70{ }^{\circ} \mathrm{C}$ until use. Total RNA was measured using a nano spectrophotometer (Optizen, Korea).

\section{Quantitative real-time RT-PCR}

Single-stranded cDNA was synthesized from 1 to $2 \mu \mathrm{g}$ RNA using a Quantitect ${ }^{\circ}$ Reverse Transcription Kit (Qiagen, Hilden, Germany) according to the manufacturer's instructions. Real-time RT-PCR was performed in duplicate using a CFX96 real-time RT-PCR system (Bio-Rad, USA) with SYBR Green (Bioneer, Korea). Expression levels of target genes were determined using the primers shown in Table 1. Gene expression levels were quantified using $\Delta \Delta C_{t}$ [40]. The $\beta$-actin gene was used as the reference to normalize the relative expression levels of individual transcripts. The data were analyzed using the Bio-Rad CFX software.

\section{Total protein extraction from spleen}

The total protein from spleen was extracted by RIPA buffer (sc-24,948, Santa Cruz Biotechnology, Texas, USA) in following the manufacturer's protocol. Briefly, frozen spleens were thawed and homogenized in RIPA buffer containing protease inhibitor cocktail (PIC). The lysates were then centrifuged at $10,000 \times g$ at $4{ }^{\circ} \mathrm{C}$ for $10 \mathrm{~min}$ and the supernatant containing total proteins was collected.

\section{Collection of nuclear protein extracts from macrophages} Macrophages were prepared with cold PBS wash and collected with a cell scraper and centrifuged at $1500 \times \mathrm{g}$ at $8{ }^{\circ} \mathrm{C}$ for $5 \mathrm{~min}$. Buffer A (10 mM HEPES, pH 7.9, $10 \mathrm{mM} \mathrm{KCl}, 1.5 \mathrm{mM} \mathrm{MgCl} 2,1 \mathrm{mM}$ DTT) was used to resuspend the cells, and the suspension was frozen in a dry-acetone bath. Cells were thawed in an ice bath followed by centrifugation at $1200 \times \mathrm{g}$ at $4{ }^{\circ} \mathrm{C}$ for

Table 1 Primer sequences of macrophage genes used for qRT-PCR assays

\begin{tabular}{|c|c|c|}
\hline Gene name & Forward primer & Reverse primer \\
\hline$b$-actin & 5'-CGCCACCAGTTCGCCATGGA-3' & 5'-TACAGCCCGGGGAGCATCGT-3 \\
\hline 1116 & 5'-CAACCACACAAGTGATATTCTC-3' & 5'-GGATCCACACTCTCCAGCTGC-3 \\
\hline 116 & 5'-TCCAGTTGCCTTCTTGGGAC-3' & 5'-GTACTCCAGAAGACCAGAG-3' \\
\hline Tnf & $5^{\prime}$-CACAGAAAGCATGATCCGCGA-3' & 5'-CGGCAGAGAGGAGGTTGACTT-3' \\
\hline $1 / 10$ & 5'-TGGCCCAGAAATCAAGGAGC-3' & 5'-CAGCAGACTCAATACACACT-3' \\
\hline Ifng & 5'-TGAACGCTACACACTGCATCT-3' & 5'-CGACTCCTTTTCCGCTTCCTG-3' \\
\hline Mcp 1 & 5'- GGTCCCTGTCATGCTTCTGGG-3' & 5'-TCCAGCCTACTCATTGGGATC-3' \\
\hline P50 & 5'-CTCACTCAATATTTAATGCAG-3' & 5'-CCCTCCGTGTGATGGGCCTTC-3' \\
\hline P52 & 5'-CCCATGGAGGTTTGCCAGGTG-3' & 5'-CCCACCAGACTGTGGGCATGC-3' \\
\hline P65 & 5'-CATCCACATGAACTTGTGGGG-3' & 5'-CTGGCTAATGGCTTGCTCCAG - 3' \\
\hline
\end{tabular}


$10 \mathrm{~min}$. The supernatant containing the cytoplasmic extracts and the pellet containing the nuclei were separated. Buffer C (20 mM HEPES, pH 7.9, $0.4 \mathrm{M} \mathrm{NaCl}$, $1.5 \mathrm{mM} \mathrm{MgCl} 2,25 \%$ glycerol, $0.2 \mathrm{mM}$ EDTA, $1 \mathrm{mM}$ DTT), supplemented with $0.5 \mathrm{mM}$ phenylmethylsulfonyl fluoride (PMSF, Sigma-Aldrich, CA, USA) protease inhibitor was used to resuspend the pellet. This suspension was incubated at $4{ }^{\circ} \mathrm{C}$ for $30 \mathrm{~min}$ with gentle stirring in an angular position and then centrifuged at 20,000 $\mathrm{x} g$ at $4{ }^{\circ} \mathrm{C}$ for $20 \mathrm{~min}$. The supernatant collected from this suspension was the final nuclear extract, which was added to Buffer D (20 mM HEPES, pH 7.9, $50 \mathrm{mM}$ $\mathrm{KCl}, 25 \%$ glycerol, $0.2 \mathrm{mM}$ EDTA, $1 \mathrm{mM}$ DTT) supplemented with $0.5 \mathrm{mM}$ PMSF. The same buffer was added to the cytoplasmic extract, and both extracts were stored at $-70{ }^{\circ} \mathrm{C}$. Protein concentrations were determined with the bicinchoninic acid reaction (BCA, Pierce, Rockford, IL) [41].

\section{Immunoblot analysis}

Immunoblot analysis was carried out according to the previously reported method [42]. Proteins extracted from RAW 264.7 cells and splenic cells as well as from nuclear extracts from macrophages were evaluated for a variety of proteins. Cells were cultured in 6-well plates, infected with $B$. abortus for the indicated time, incubated at $37{ }^{\circ} \mathrm{C}$ for $2 \mathrm{~h}$, followed by incubation at $43{ }^{\circ} \mathrm{C}$ for $1.5 \mathrm{~h}$ and returned back to $37{ }^{\circ} \mathrm{C}$ for $24 \mathrm{~h}$. Cells were washed with ice-cold PBS twice and lysed with ice-cold radioimmunoprecipitation assay (RIPA) buffer containing $1 \%$ protease inhibitor cocktail for $30 \mathrm{~min}$ at $4{ }^{\circ} \mathrm{C}$. Samples were separated by SDS-PAGE. The proteins were transferred to Immobilon-P membranes (Millipore, USA) using 1X transfer buffer ( $25 \mathrm{mM}$ Tris, $192 \mathrm{mM}$ glycine and 20\% methanol) with a constant current of $2 \mathrm{~mA} / \mathrm{cm}^{2}$ for $1.5 \mathrm{~h}$ in a semi-dry electroblot assembly (Bio-Rad, USA). The membrane was blocked with $5 \%(w / v)$ skim milk in $1 \mathrm{X}$ Tris-buffered saline-Tween 20 (TBS-T) $(20 \mathrm{mM}$ Tris- $\mathrm{HCl}, 150 \mathrm{mM} \mathrm{NaCl}$, Tween $0.1 \%, \mathrm{pH} 7.6$ ) for $30 \mathrm{~min}$ at room temperature. The membranes were incubated with phospho-specific antibodies against HSP70, HSP90, intact or cleaved Caspase 3, p50, p52, p65 or iNOS overnight at $4{ }^{\circ} \mathrm{C}$. All antibodies were obtained from Cell Signaling (USA). Binding of the primary antibody was detected with a horseradish peroxidase (HRP)-conjugated secondary antibody (Thermo Scientific, USA; 1:1000 dilution) in 5\% blocking buffer for $1 \mathrm{~h}$ followed by a wash with $1 \mathrm{X}$ TBS-T. The signal was detected using a luminal-coumaric acid- $\mathrm{H}_{2} \mathrm{O}_{2}$ detection solution (Atto Corporation, Japan) and a Molecular Imager ${ }^{\circ}$ ChemiDoc $^{\text {tw }}$ XRS+ system machine (Bio-Rad Laboratories, USA).

\section{Indirect immunofluorescence}

RAW 264.7 macrophages at $10^{6}$ cells per well were infected with $B$. abortus and incubated for $24 \mathrm{~h}$ at $37^{\circ} \mathrm{C}$ in $5 \% \mathrm{CO}_{2}$. Cells were then fixed with $4 \%$ paraformaldehyde, incubated at $37{ }^{\circ} \mathrm{C}$ for $1 \mathrm{~h}$, permeabilized with $0.1 \%$ Triton $\mathrm{X}-100$ for $10 \mathrm{~s}$ at $4{ }^{\circ} \mathrm{C}$ and incubated with blocking buffer ( $2 \%$ goat serum in PBS) for $1 \mathrm{~h}$. Rabbit anti-mouse NF- $\kappa B$ p65 and FITC-conjugated anti-rabbit IgG were subsequently added as primary and secondary antibodies (Santa Cruz), respectively. The cells were mounted with Permafluor mounting medium and analyzed by using a laser scanning confocal microscope (Olympus FV1000, Japan). The images were processed using FV10-ASW Viewer 3.1 software.

\section{ROS and NO detection}

RAW 264.7 cells at $10^{6}$ cells per well were infected with B. abortus followed by heat exposure at $43{ }^{\circ} \mathrm{C}$ for $1.5 \mathrm{~h}$ and incubated for $24 \mathrm{~h}$ at $37{ }^{\circ} \mathrm{C}$. The ROS content was then evaluated by fluorescence microscopy (Total ROS detection kit, ENZ-51011, Enzo Life Sciences) and spectrometry (DCFDA cellular ROS detection assay kit, Ab113851, Abcam) according to the manufacturer's instructions. The nitrite concentration of culture supernatants was also assessed by the Griess reaction (Sigma).

\section{Cytokine quantitation}

The levels of IL-6, IL-10, IFN- $\gamma$, TNF and MCP-1 in serum samples were determined by cytometric bead arrays (BD CBA Mouse Inflammation Kit, USA), and the level of IL-1 $\beta$ in serum samples was determined by sandwich ELISAs (Abcam, USA) following the manufacturer's protocol.

\section{Flow cytometry for apoptosis}

The apoptosis was evaluated by flow cytometry using Apoptosis detection kit (Abcam) at $48 \mathrm{~h}$ pi in accordance with the manufacturer's instructions. Briefly, infected macrophages at $10^{6}$ cells per well were exposed to $43{ }^{\circ} \mathrm{C}$ for $1.5 \mathrm{~h}$, incubated for $48 \mathrm{~h}$ at $37{ }^{\circ} \mathrm{C}$ and then stained with apopxin green. The apoptosis was determined from 10,000 events.

\section{Statistical analysis}

Data were statistically analyzed using the Student's t-test or ANOVA with Tukey's HSD (Honestly Significant Difference) exact test to compare differences between the groups. Data were considered statistically significant if $p<0.05$. Data were expressed as the mean \pm standard error (SE).

\section{Abbreviations}

BCA: bicinchoninic acid; CDC: Centers for Disease Control and Prevention; CFU: colony forming unit; DMEM: Dulbecco's modified eagle medium; FBS: fetal bovine serum; HSP: heat shock protein; IFN: interferon;

IL: interleukin; iNOS: inducible nitric oxide synthase; LPS: lipopolysaccharide; MCP-1: monocyte chemoattractant protein-1; MOI: multiplicity of infection; NF: nuclear factor; NO: nitric oxide; PBS: phosphate buffer saline; 
PMSF: phenylmethylsulfonyl fluoride; RIPA: radioimmunoprecipitation assay; ROS: reactive oxygen species; TLR: Toll-like receptor; TNF: tumor necrosis factor

\section{Funding}

This research was supported by a grant of the Korea Health Technology R\&D Project through the Korea Health Industry Development Institute (KHIDI), funded by the Ministry of Health \& Welfare, Republic of Korea (Grant number: HI6C2130)

\section{Authors' contributions}

HTH, LTA, AWBR and HTXN carried out all experiments, contributed to data collection and analysis, and participated in drafting the manuscript; WGM, $\mathrm{HJ}, \mathrm{MHR}$ and $\mathrm{HHC}$ participated in the design of the study and contributed to the bacterial preparation and immunoblotting; KS participated in the design of the study, carried out the data analysis, conceived the experiment and prepared the manuscript. All authors read and approved the final manuscript.

\section{Ethics approval and consent to participate}

All of the procedures performed were reviewed and approved by the Animal Ethical Committee of Gyeongsang National University (Authorization Number GNU-120423-M0012).

\section{Competing interests}

The authors declare that they have no competing interests.

\section{Publisher's Note}

Springer Nature remains neutral with regard to jurisdictional claims in published maps and institutional affiliations.

\section{Author details}

${ }^{1}$ Institute of Animal Medicine, College of Veterinary Medicine, Gyeongsang National University, Jinju 52828, Republic of Korea. ${ }^{2}$ College of Veterinary Medicine, Kyungpook National University, Daegu 42566, Republic of Korea. ${ }^{3}$ Institute of Agriculture and Life Science, Gyeongsang National University, Jinju 52828, Republic of Korea.

\section{Received: 2 July 2017 Accepted: 14 May 2018}

\section{Published online: 25 May 2018}

\section{References}

1. Villar J, Ribeiro SP, Muller JB, Kuliswewski M, Post M, Slutsky AS. Induction of the heat shock response reduces mortality and organ damage in a sepsisinduced acute lung injury model. Crit Care Med. 1994;22:914-21.

2. Wong HR, Wisp JR. The stress response and the lung. Am J Phys. 1997;273:1-9.

3. Zhou J, An H, Xu H, Liu S, Cao X. Heat shock up-regulates expression of tolllike receptor-2 and toll-like receptor- 4 in human monocytes via p38 kinase signal pathway. Immunol. 2005;114(4):522-30.

4. Akira S. Pathogen recognition and innate immunity. Cell. 2006;124:783-801.

5. Kawai T, Akira S. Signaling to NF-KB by toll-like receptors. Trends Mol Med. 2007;13(11):460-9.

6. Tak P, Firestein GS. NFkB: A key role in inflammatory diseases. J Clin Invest. 2001;7(1):7-11.

7. Pogliaghi G, Tacchini L, Arzon E, Radice L, Bernelli-Zazzera A. Heat shock activation of NF-KB in rat liver is mediated by interleukin 1. FEBS Lett. 1995; 372:181-4.

8. Lee CT, Repasky E. Opposing roles for heat and heat shock proteins in macrophage functions during inflammation: a function of cell activation state? Front Immunol. 2012;3:1-7.

9. Vega V, Alexander L, Charles W, Hwang J, Nizet V, Maio A. Activation of the stress response in macrophages alters the M1/M2 balance by enhancing bacterial killing and IL10 expression. J Mol Med. 2014;92(12):1305-17.

10. Sona L, Fujita J, Gafffin S, Lilly M. Molecular biology of thermoregulation invited review: effects of heat and cold stress on mammalian gene expression. J Appl Physiol. 2002;92:1725-42.

11. Lee W, Moon M, Kim HG, Lee TH, Oh MS. Heat stress induced memory impairment is associated with neuroinflammation in mice. Neuroinflammation. 2015;12:102.
12. Lee JJ, Simborio HL, Reyes AW, Kim DG, Hop HT, Min W, Her M, Jung SC, Yoo HS, Kim S. Immunoproteonomic identification of immunodominant antigens independent of the time of infection in Brucella abortus 2308-challenged cattle. Vet Res. 2015:46:17. https:/doi.org/10.1186/s13567-015-0147-6.

13. Gomez G, Adams LG, Rice-Ficht A. Host-Brucella interactions and the Brucella genome as tools for subunit antigen discovery and immunization against brucellosis. Front Cell Infect Microbiol. 2013;3:1-15.

14. Guzman-Verri C. GTPases of the rho subfamily are required for Brucella abortus internalization in nonprofessional phagocytes: direct activation of Cdc42. J Biol Chem. 2001;276:44435-43.

15. Barquero-Calvo E, Olarte E, Weiss D, Guzman-Verri C, Diaz C. Brucella uses a stealthy strategy to avoid activation of the innate immune system during the onset of infection. PLoS One. 2007:2(7):e631.

16. Ceruti S, Beltrami E, Matarrese P, Mazzola A, Cattabeni F, Malorni W, Abbracchio M. A key role for caspase-2 and caspase-3 in the apoptosis induced by 2-chloro-2'-deoxy-adenosine (cladribine) and 2-chloroadenosine in human astrocytoma cells. Mol Pharmacol. 2003;63:1437-47.

17. Macedo G, Magnani D, Carvalho N, Bruna-Romero O, Gazzinelli R, Oliveira S. Central role of MyD88-dependent dendritic cell maturation and proinflamatory cytokine production to control Brucella abortus infection. J Immunol. 2008;180:1080-7.

18. Elfaki MG, Alaidan AA, Al-Hokail AA. Host response to Brucella infection: review and future perspective. J Infect Dev Ctries. 2015;9(7):697-701. https:// doi.org/10.3855/jidc.6625.

19. Colaco CA, Bailey CR, Walker KB, Keeble J. Heat shock proteins: stimulators of innate and acquired immunity. Bio Med Res Int. 2013;2013:461230.

20. Demeester S, Buchman T, Cobb J. The heat shock paradox: does NF-KB determine cell fate? The FASEB J. 2016;15(1):270-4.

21. Giambartolomei GH, Zwerdling A, Cassataro J, Bruno L, Fossati CA, Philipp MT. Lipoproteins, not lipopolysaccharide, are the key mediators of the proinflammatory response elicited by heat killed Brucella abortus. J Immunol. 2004;173:4635-42.

22. Berguer PM, Mundinano J, Piazzon I, Goldbaum FA. A polymeric bacterial protein activates dendritic cells via TLR4. J Immunol. 2006;176:2366-72.

23. Oliveira SC, de Oliveira FS, Macedo GC, de Almeida LA, Carvalho NB. The role of innate immune receptors in the control of Brucella abortus infection: toll-like receptors and beyond. Microbes Infect. 2008;10:1005-9.

24. Gilmore TD. Introduction to NF-kappa Beta: players, pathways, perspectives. Oncogene. 2006;25:6680-4.

25. Karin M, Greten FR, NF-kappa B. Linking inflammation and immunity to cancer development and progression. Nat Rev Immunol. 2005;5:749-59.

26. Ostberg JR, Taylor SL, Baumann H, Repasky EA. Regulatory effects of feverrange whole-body hyperthermia on the LPS-induced acute inflammatory response. J Leukoc Biol. 2000;68:815-20.

27. Cardoso P, Macedo G, Azevedo V, Oliveira S. Brucella spp. noncanonical LPS: structure, biosynthesis, and interaction with host immune system. Microb Cell Factories. 2006;5:13. https://doi.org/10.1186/1475-2859-5-13.

28. Lopez-Urrutia L, Alonso A, Nieto M, Bayon Y, Orduña A, Sanchez-Crespo M Lipopolysaccharides of Brucella abortus and Brucella melitensis induce nitric oxide synthesis in rat peritoneal macrophages. Infect Immun. 2000;68:1740-5.

29. Jiang $X$, Leonard B, Benson R, Baldwin C. Macrophage control of Brucella abortus: role of ROS intermediates and nitric oxide. Cell Immunol. 1993:151:309-19.

30. Brandao M, Oliveira I, Carvalho N, Vieira L. Host susceptibility to Brucella abortus infection is more pronounced in IFN- $\gamma$ than IL12/B2-microglobulin deficient mice. Clin Dev Immunol. 2011. 2012:589494. https://doi.org/10. 1155/2012/589494.

31. Netea M, Simon A, Veerdonk I, Kullberg B. IL1 $\beta$ Processing in host defense: Beyond the inflammasomes. PLoS Pathog. 2010;6(2):e1000661. https://doi. org/10.1371/journal.ppat.1000661

32. Gorvel J, Papadopoulos A, Gagnaire A, Degos C, de Chastellier C. Brucella discriminates between mouse dendritic cell subsets in vitro infection. 2015; 7(1):33-4. https://doi.org/10.1080/21505594.2015.1108516.

33. Pritchard M, Li Z, Repasky E. Nitric oxide production is regulated by fever-range thermal stimulation of murine macrophages. J Leukoc Biol. 2005;78:630-8.

34. Gomes M, Almeida L, Campos P, Oliveira S. The role of innate immune signals in immunity to Brucella abortus. Front Cell Infect Microbiol. 2012;2: 130. https://doi.org/10.3389/fcimb.2012.

35. Jimenez de- Bagues M, Dudal S, Dornand J, Gross A. Cellular bioterrorism: how Brucella corrupts macrophage physiology to promote invasion and proliferation. Clin Immunol. 2005;114(3):227-38. 
36. Zhou H, Monach OM, Kayagaki N, Wertz I, Yin J, Wolf B, Dixit VM. Yersinia virulence factor Yop J acts as a deubiquitinase to inhibit NF-kappa $\beta$ activation. J Exp Med. 2005;202:1327-32.

37. Weischenfeldt J, Porse B. Bone marrow-derived macrophages (BMM): isolation and applications. CSH Protoc. 2008; https://doi.org/10.1101/pdb. prot5080.

38. Lee JJ, Kim DH, Kim DG, Min W, Rhee MH, Yun BS, Kim S. Phelinuus baumii extract influences pathogenesis of Brucella abortus in phagocyte by disrupting the phagocytic and intracellular trafficking pathway. J Appl Microbiol. 2013;114(2):329-38.

39. Schemione M, Elling C, Steild U, Baumer U, Hamilton A, Spieker T. BCR-ABL enhances differences of long-term repopulating hematopoietic stem cells. Blood. 2010;115:3185-95.

40. Livak KJ, Schmittgen TD. Analysis of relative gene expression data using real-time quantitative PCR and the 2- $\Delta \Delta C \mathrm{Ct}$ method. Methods. 2001;25:402-8.

41. Cervantes M, Martinez A, Ramirez G, Saucedo M, Moreno M, Lopez R, Estrada I, Mojica A. Regulation of cytokine gene expression during Brucella abortus infection. Sci Res Essays. 2013;8(22):983-91.

42. MacPhee DJ. Methodological considerations for improving western blot analysis. J Pharmacol Toxicol Methods. 2010;61(2):171-7.

Ready to submit your research? Choose BMC and benefit from:

- fast, convenient online submission

- thorough peer review by experienced researchers in your field

- rapid publication on acceptance

- support for research data, including large and complex data types

- gold Open Access which fosters wider collaboration and increased citations

- maximum visibility for your research: over $100 \mathrm{M}$ website views per year

At BMC, research is always in progress.

Learn more biomedcentral.com/submissions 